\title{
Potensi Ekstrak Kasar Teripang Holothuria atra, Jaeger, 1833 (Holothuroidea : Holothuriidae) Dari Pulau Panjang, Jepara
}

\author{
Sonny Rieldo Damanik*, Bambang Yulianto, Subagiyo \\ Departemen IImu Kelautan, Fakultas Perikanan dan IImu Kelautan, Universitas Diponegoro \\ JI. Prof. H. Soedarto S.H, Tembalang,Semarang, Jawa Tengah 50275 Indonesia \\ ${ }^{*}$ Corresponding author, e-mail: sonny_damanik@student.undip.ac.id
}

\begin{abstract}
ABSTRAK : Aktivitas antibakteri yang terdapat dalam Holothuria atra dapat dimanfaatkan sebagai makanan fungsional yang dapat mengendalikan mikroflora dalam saluran pencernaan. Tujuan dari penelitian ini adalah untuk mengetahui potensi aktivitas antibakteri dari teripang $H$. atra terhadap bakteri $B$. cereus (gram positif) dan $V$. alginolyticus (gram negatif) sebagai foodborne pathogens. Sampel teripang $H$. atra diambil dari ekosistem lamun perairan Pulau Panjang dengan metode purposive sampling method untuk mengambil teripang berukuran panjang $>16 \mathrm{~cm}$ sebanyak $1 \mathrm{~kg}$. Sampel $H$. atra dibersihkan lalu dipisahkan antara daging dan jeroannya, kemudian di maserasi menggunakan pelarut etil asetat dengan perbandingan 1:3 (w:v) selama 1x24 jam. Hasil maserasi diuapkan dengan rotary evaporator pada suhu $38^{\circ} \mathrm{C}$. Ekstrak daging dan jeroan yang diperoleh adalah $669,8 \mathrm{mg}$ dan $625,2 \mathrm{mg}$. Uji aktivitas antibakteri dilakukan dengan metode paper disk

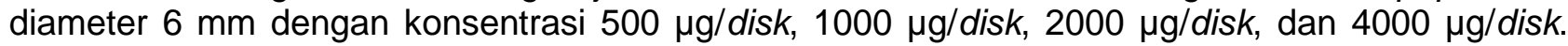
Aktivitas antibakteri yang diperoleh dari perbedaan konsentrasi yang diberikan berbeda secara nyata dengan adanya peningkatan Activity Unit $(A U)$ di setiap kenaikan konsentrasi. Aktivitas antibakteri terbesar yang diperoleh dari ekstrak daging $H$. atra pada konsentrasi $4000 \mu \mathrm{g} /$ disk terhadap bakteri $V$. alginolyticus (gram negatif) dan $B$. cereus (gram positif) masing-masing adalah $14214,08 \mathrm{~mm}^{2} / \mathrm{ml}$ dan $10508,62 \mathrm{~mm}^{2} / \mathrm{ml}$. Aktivitas antibakteri terbesar yang diperoleh dari ekstrak jeroan $H$. atra pada konsentrasi $4000 \mu \mathrm{g} /$ disk terhadap bakteri $V$. alginolyticus (gram negatif) dan $B$. cereus (gram positif) masing-masing adalah $7858,72 \mathrm{~mm}^{2} / \mathrm{ml}$ dan $4919,68 \mathrm{~mm}^{2} / \mathrm{ml}$. Berdasarkan penelitian ini, daging dan jeroan teripang $H$. atra keduanya memiliki aktivitas antibakteri terhadap bakteri $B$. cereus (gram positif) dan $V$. alginolyticus (gram negatif).
\end{abstract}

Kata Kunci : Antibakteri, Foodborne pathogen, Holothuria atra, Makanan fungsional

\section{Potential of Sea Cucumber Raw Extract Holothuria atra, Jaeger, 1833 (Holothuroidea: Holothuriidae) From Panjang Island, Jepara}

\begin{abstract}
The antibacterial activity contained in the bioactive compounds of sea cucumber Holothuria atra can be used as functional foods that can control microflora in the digestive tract. The purpose of this study was to determine the potential antibacterial activity of sea cucumber $\mathrm{H}$. atra against $B$. cereus (gram positive) and $V$. alginolyticus (gram negative) as foodborne pathogens. The samples of $H$. atra in this study were taken from the seagass ecosystem of Panjang Island waters using the purposive sampling method so that the sea cucumbers taken were $>16 \mathrm{~cm}$ long. The obtained sea cucumber samples were cleaned and separated between the meat and the viscera, then macerated using ethyl acetate with a ration of 1:3 (w/v) for 24 hours. The solvent was evaporated using rotary evaporator at $38^{\circ} \mathrm{C}$. The obtained meat and viscera extract of $\mathrm{H}$. atra in this study were $669,8 \mathrm{mg}$ and $625,2 \mathrm{mg}$. The antibacterial activity test was carried out using the diffusion method with a $6 \mathrm{~mm}$ paper disk (Kirby-Bauer Method), and the concentrations of each extract are $500 \mu \mathrm{g} /$ disk, $1000 \mu \mathrm{g} /$ disk, $2000 \mu \mathrm{g} / \mathrm{disk}$, and $4000 \mu \mathrm{g} / \mathrm{disk}$. The antibacterial activity of extracts from different concentrations were significantly different in line with the increasing results of activity unit $(A U)$ at each increased concentration. The largest activity unit was obtained from meat extract at a concentration of $4000 \mu \mathrm{g} /$ disk. The antibacterial activity unit from meat extract against $V$. alginolyticus (gram-negative) and B. cereus (gram-positive) are $14214,08 \mathrm{~mm} 2 / \mathrm{ml}$ and 10508,62 $\mathrm{mm} 2 / \mathrm{ml}$. The largest antibacterial activity unit of viscera extract against $V$. alginolyticus and $B$. cereus are $7858,72 \mathrm{~mm} / \mathrm{ml}$ and $4919,68 \mathrm{~mm} / \mathrm{ml}$. Based on this
\end{abstract}


study, meat and viscera extracts from $H$. atra both have antibacterial activity against $B$. cereus (gram-positive) and $V$. alginolyticus (gram-negative).

Keywords: Antibacterial, Foodborne pathogen, Holothuria atra, Functional food

\section{PENDAHULUAN}

Teripang merupakan biota laut yang termasuk ke dalam golongan hewan Echinodermata. Teripang $H$. atra hidup di habitat berpasir atau habitat yang agak lunak (pasir berlumpur). Teripang $H$. atra merupakan salah satu spesies teripang yang mampu beradaptasi dengan baik (Wiranto et al., 2016). Metabolit sekunder teripang memiliki senyawa bioaktif yang diantaranya adalah alkaloid, saponin, triterpenoid, flavonoid, dan steroid (Pranoto et al., 2012). Farouk (2007) menjelaskan dalam penelitiannya bahwa teripang Holothuria atra dapat dimanfaatkan sebagai sumber makanan fungsional karena memiliki potensi antikoagulan, antikanker, antitumor, antibakteri, antijamur, antimalaria, meningkatkan imunitas, antirematik dan antivirus.

Makanan fungsional adalah makanan atau bahan pangan yang dapat memberikan manfaat tambahan di samping fungsi gizi dasar pangan (European Commision Concerted Action on Functional Food Science in Europe, 1999). Menurut Khotimchenko (2018), aktivitas antibakteri yang dimiliki oleh senyawa bioaktif teripang dapat dimanfaatkan sebagai pengendali bakteri dalam tubuh dan meningkatkan imunitas tubuh.

Bakteri patogen dapat masuk kedalam tubuh manusia ataupun hewan melalui makanan atau minuman yang kurang higienis. Beberapa jenis bakteri patogen yang masuk melalui makanan atau minuman digolongkan kedalam jenis Foodborne Pathogen. Aktivitas antibakteri yang dimiliki oleh senyawa bioaktif teripang menurut Kaswandi et al. (2000) dapat dimanfaatkan untuk menghambat pertumbuhan bakteri, sehingga aktivitas antibakteri dari teripang tersebut dapat dimanfaatkan untuk mengendalikan mikroflora yang terdapat dalam saluran pencernaan manusia ataupun hewan. Potensi antibakteri yang dimiliki oleh teripang tersebut menyebabkan perlunya diadakan penelitian mengenai uji aktivitas antibakteri dari teripang $H$. atra untuk mengetahui aktivitas antibakteri dari ekstrak teripang $H$. atra.

\section{MATERI DAN METODE}

Materi pada penelitian ini menggunakan teripang Holothuria atra yang diambil dari ekosistem lamun perairan Pulau Panjang, serta bakteri $B$. cereus (gram positif) dan $V$. alginolyticus (gram negatif) sebagai bakteri uji. Penelitian uji aktivitas antibakteri dari ekstrak kasar teripang $H$. atra dari Pulau Panjang ini dilakukan menggunakan metode experimental laboratory.

Teripang Holothuria atra diambil dari perairan Pulau Panjang, Jepara. Sampel teripang diambil dengan purposive sampling method untuk mendapatkan teripang yang telah memasuki stadia dewasa dengan kriteria yaitu berukuran $\geq 16 \mathrm{~cm}$ dengan berat kotor $\geq 100$ gram (Darsono, 1999). Teripang diambil sebanyak \pm 1 kilogram dan dimasukkan kedalam cool box berisikan air laut dan sedimen, sampel teripang tetap segar saat sampai laboratorium.

Sampel teripang dimatikan dengan cara membelah tubuh teripang secara memanjang lalu dipisahkan antara daging dan jeroannya. Sampel teripang $H$. atra selanjutnya dibersihkan dengan air tawar kemudian dicincang menggunakan pisau.

Analisis kadar air ini bertujuan untuk mengetahui berat kering dari sampel basah yang digunakan. Cara kerja metode ini, yaitu cawan kosong dipanaskan dalam oven pada temperature 105ㄷ selama 30 menit, didinginkan dalam desikator selama 15 menit, lalu ditimbang $\left(\mathrm{W}_{0}\right)$. Kemudian masing-masing sampel sebanyak 2 gram dimasukan pada cawan yang telah diketahui bobotnya, ditimbang $\left(\mathrm{W}_{1}\right)$, lalu dikeringkan dalam oven pada suhu $105^{\circ} \mathrm{C}$ selama 3 jam, didinginkan dalam eksikator selama 15-30 menit, kemudian cawan dan isinya ditimbang dan dikeringkan kembali selama 1 jam, serta didinginkan didalam eksikator, ditimbang kembali $\left(\mathrm{W}_{2}\right)$. Menurut Winarno (2004), Kandungan air dihitung dengan rumus: 


$$
\text { Kadar air }(\%)=\frac{(W I-W 2)}{(W I-W 0)} \times 100
$$

Keterangan : $\mathrm{W}_{0}=$ berat cawan kosong; $\mathrm{W}_{1}=$ berat cawan + sampel awal; (sebelum pemanasan dalam oven); $W_{2}$ = berat cawan + sampel awal (setelah pendinginan dalam eksikator)

Sampel basah daging dan jeroan dari $H$. atra yang telah di cincang diambil masing-masing $300 \mathrm{~g}$ untuk diekstrak menggunakan metode maserasi tunggal. Sampel $H$. atra direndam dalam $\mathrm{C}_{4} \mathrm{H}_{8} \mathrm{O}_{2}$ (etil asetat) dengan perbandingan 1:3 (w/v) selama $1 \times 24$ jam. Residu kemudian disaring dengan vacuum pump menggunakan kertas whatman berbentuk lingkaran berdiameter $150 \mathrm{~mm}$ dengan kerapatan pori 11 mikron. Air yang terdapat dibagian bawah dari filtrat dipisahkan menggunakan separatory funnel kemudian di evaporasi dengan rotary evaporator pada suhu $38^{\circ} \mathrm{C}$ (Sari et al., 2014).

Uji aktivitas antibakteri dilakukan dengan metode difusi agar (Kirby-Bauer) menggunakan kertas cakram / papper disc $6 \mathrm{~mm}$ yang diujikan secara duplo. Aktivitas antibakteri ditandai dengan munculnya zona hambat. Zona hambat diukur menggunakan jangka sorong dengan tiga kali pengukuran disetiap masing-masing pengulangan (Sabdono dan Radjasa, 2008).

Ekstrak daging dan jeroan $H$. atra dilarutkan dalam DMSO (Dimethyl sulfoxide) untuk mendapatkan larutan stock dengan konsentrasi $4000 \mu \mathrm{g} / \mathrm{ml}$. Pada penelitian dari Sari et al. (2014) pengujian aktivitas antibakteri dilakukan pada konsentrasi $500 \mu \mathrm{g} /$ disk, $1000 \mu \mathrm{g} /$ disk, $2000 \mu \mathrm{g} /$ disk, dan $4000 \mu \mathrm{g} /$ disk. Larutan stock diencerkan menggunkan DMSO untuk memperoleh konsentrasi $2000 \mu \mathrm{g} / 10 \mu \mathrm{L}, 1000 \mu \mathrm{g} / 10 \mu \mathrm{L}$, dan $500 \mu \mathrm{g} / 10 \mu \mathrm{L}$ yang kemudian ditetesken dengan volume $10 \mu \mathrm{L}$ pada paper disc diameter $6 \mathrm{~mm}$ dan diletakkan diatas media NA dicawan petri yang telah diinokulasi bakteri uji (B. cereus dan $V$. alginolyticus) dengan kepadatan 0,5 standar McFarland.

Kontrol positif yang digunakan pada penelitian ini adalah kloramfenikol dengan konsentrasi $500 \mu \mathrm{g} /$ disk dan pelarut DMSO sebagai kontrol negatif. Cawan petri yang sudah diberikan paper disk berisi ekstrak kemudian di inkubasi selama $2 \times 24$ jam dengan suhu $37^{\circ} \mathrm{C}$. Pengamatan dilakukan setiap 1x24 jam dan diameter zona hambat yang terbentuk diukur sebanyak tiga kali (Gambar 2). Aktivitas antibakteri menurut Usmiati et al. (2007) dapat dihitung dengan rumus :

$$
\text { Activity Unit }\left(\mathrm{mm}^{2} / \mathrm{ml}\right)=\frac{L z-L S}{\mathrm{~V}}
$$

Keterangan: $\mathrm{Lz}=$ Luas zona hambat $\left(\mathrm{mm}^{2}\right) ; \mathrm{Ls}=$ Luas paper disk $\left(\mathrm{mm}^{2}\right) ; \mathrm{V}=$ Volume $(0,01 \mathrm{ml})$

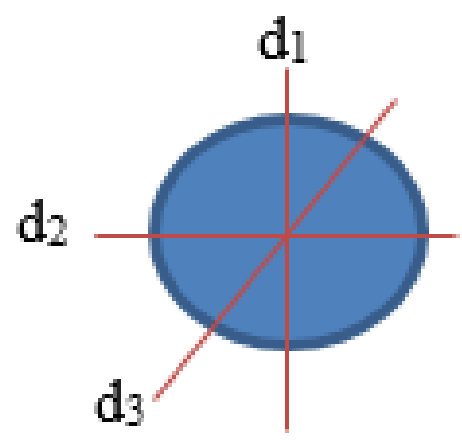

Gambar 2. Cara Pengukuran $d_{1}, d_{2}$, dan $d_{3}$

\section{HASIL DAN PEMBAHASAN}

Pada penelitian ini, hasil ekstrak daging dan jeroan dari teripang $H$. atra dengan berat basah masing-masing 300 gram adalah $669,8 \mathrm{mg}$ dan 625,2 mg. Bentuk ekstrak dari daging maupun jeroan $H$. atra keduanya berbentuk pasta. Warna pada ekstrak daging adalah merah bata, dan jeroan adalah merah kekuningan. 
Proses ekstraksi teripang menggunakan sampel basah karena menurut penelitian Sari et al. (2014) keadaan sampel basah lebih unggul dibandingkan keadaan sampel kering. Sampel basah masih mengandung senyawa alkaloid, sedangkan pada sampel kering tingkat alkaloidnya akan berkurang bahkan dapat hilang karena pengaruh pemanasan. Alkaloid merupakan senyawa yang dapat menghambat dan merusak dinding sel bakteri sehingga dapat menghambat pertumbuhan bakteri (Cushnie et al., 2014).

Berat ekstrak daging $H$. atra lebih besar dibandingkan berat ekstrak jeroan $H$. atra menurut Inayah et al. (2013) disebabkan oleh perbedaan jumlah senyawa yang berhasil diikat oleh pelarut. Pernyataan tersebut diperkuat melalui penelitian Oktaviani et al. (2015) yang membuktikan bahwa dalam ekstrak jeroan teripang memiliki senyawa metabolit sekunder alkaloid, triterpenoid, dan saponin dengan kadar yang lebih rendah dibandingkan ekstrak daging teripang.

Bentuk ekstrak yang dihasilkan berupa pasta disebabkan karena sampel yang digunakan pada ekstraksi ini adalah sampel basah (kadar air daging $82 \%$ dan jeroan $84 \%$ ). Perbedaan warna dapat disebabkan karena perbedaan jumlah senyawa metabolit sekunder yang terikat kedalam pelarut. Warna merah bata pada ekstrak daging teripang disebabkan oleh kandungan senyawa triterpenoid, dan warna kekuningan disebabkan oleh kandungan senyawa alkaloid yang terkandung didalam ekstrak teripang (Oktaviani et al., 2015).

Hasil penelitian uji aktivitas antibakteri ekstrak daging dan jeroan terhadap bakteri $B$. cereus dan $V$. alginolyticus menunjukkan bahwa Ekstrak daging dan jeroan $H$. atra mempunyai aktivitas antibakteri terhadap B. cereus dan V. alginolyticus. Menurut penelitian Sari et al. (2014) menyatakan bahwa salah satu faktor yang mempengaruhi luasan zona hambat adalah konsentrasi dari ekstrak tersebut. Penelitian Siti et al. (2012) juga memperkuat pendapat tersebut dengan membuktikan adanya peningkatan aktivitas antibakteri seiring dengan penambahan jumlah konsentrasi agen antibakteri.

Aktivitas antibakteri terbesar berdasarkan data setelah masa inkubasi 24 jam (Tabel 1 dan 3) terdapat pada ekstrak daging teripang dengan konsentrasi ekstrak $4000 \mu \mathrm{g} /$ disk terhadap bakteri

Tabel 1. Aktivitas Antibakteri Ekstrak Daging dan Jeroan H. atra terhadap Bakteri Bacillus cereus Inkubasi 24 jam dan 48 jam.

\begin{tabular}{ccccc}
\hline \multirow{2}{*}{$\begin{array}{c}\text { Konsentrasi Ekstrak } \\
(\mu \mathrm{g} / \text { disk })\end{array}$} & \multicolumn{4}{c}{ Activity Unit $\left(\mathrm{mm}^{2} / \mathrm{ml}\right)$} \\
\cline { 2 - 5 } & \multicolumn{2}{c}{24 jam } & \multicolumn{2}{c}{48 jam } \\
\cline { 2 - 5 } & Daging & Jeroan & Daging & Jeroan \\
\hline 500 & $0,00 \pm 0,00^{\mathrm{a}}$ & $0,00 \pm 0,00^{\mathrm{a}}$ & $0,00 \pm 0,00^{\mathrm{a}}$ & $0,00 \pm 0,00^{\mathrm{a}}$ \\
1000 & $3345,50 \pm 0,42^{\mathrm{b}}$ & $0,00 \pm 0,00^{\mathrm{b}}$ & $2603,61 \pm 0,02^{\mathrm{b}}$ & $0,00 \pm 0,00^{\mathrm{b}}$ \\
2000 & $4867,79 \pm 0,33^{\mathrm{c}}$ & $2603,61 \pm 0,26^{\mathrm{c}}$ & $4408,56 \pm 0.00^{\mathrm{c}}$ & $2366,86 \pm 0,52^{\mathrm{c}}$ \\
4000 & $10508,629 \pm 1,32^{\mathrm{d}}$ & $4919,68 \pm 1,89^{\mathrm{d}}$ & $8985,98 \pm 2,40^{\mathrm{d}}$ & $4738,81 \pm 2,05^{\mathrm{d}}$ \\
\hline
\end{tabular}

Tabel 2. Aktivitas Antibakteri Ekstrak Daging dan Jeroan $H$. atra terhadap Bakteri Vibrio alginolyticus Inkubasi 24 jam dan 48 jam

\begin{tabular}{ccccc}
\hline \multirow{2}{*}{$\begin{array}{c}\text { Konsentrasi Ekstrak } \\
(\mu \mathrm{g} / \text { disk })\end{array}$} & \multicolumn{4}{c}{ Activity Unit $\left(\mathrm{mm}^{2} / \mathrm{ml}\right)$} \\
\cline { 2 - 5 } & Daging & Jeroan & Daging & Jeroan \\
\cline { 2 - 5 } & $0,00 \pm 0,00^{\mathrm{a}}$ & $0,00 \pm 0,00^{\mathrm{a}}$ & $0,00 \pm 0,00^{\mathrm{a}}$ & $0,00 \pm 0,00^{\mathrm{a}}$ \\
500 & $5024,00 \pm 0,47^{\mathrm{b}}$ & $1570,02 \pm 0,45^{\mathrm{b}}$ & $4184,25 \pm 0,82^{\mathrm{b}}$ & $1187,12 \pm 0,45^{\mathrm{b}}$ \\
1000 & $6161,47 \pm 0,61^{\mathrm{c}}$ & $4945,70 \pm 1,67^{\mathrm{c}}$ & $5208,24 \pm, 15^{\mathrm{c}}$ & $4061,15 \pm 1,23^{\mathrm{c}}$ \\
2000 & $14214,08 \pm 0,52^{\mathrm{d}}$ & $7858,72 \pm 1,37^{\mathrm{d}}$ & $14214,08 \pm 1,15^{\mathrm{d}}$ & $7021,04 \pm 0,71^{\mathrm{d}}$ \\
4000 & & & & \\
\hline
\end{tabular}


V. alginolyticus yaitu sebesar $14214,08 \mathrm{~mm}^{2} / \mathrm{ml}$. Aktivitas antibakteri yang dihasilkan oleh ekstrak daging dengan konsentrasi ekstrak yang sama terhadap bakteri $B$. cereus menghasilkan activity unit yang lebih kecil yaitu 10508,62 $\mathrm{mm}^{2} / \mathrm{ml}$. Menurut Sari et al. (2014), hal ini terjadi karena bakteri $V$. alginolyticus memiliki struktur dinding sel yang lebih tipis dan tidak mampu untuk membentuk endospora dibandingkan bakteri $B$. cereus, sehingga aktivitas antibakteri terhadap $V$. alginolyticus lebih besar dibandingkan aktivitas antibakteri terhadap $B$. cereus.

Penurunan aktivitas antibakteri terhadap kedua bakteri setelah inkubasi 48 jam menunjukkan bahwa antibakteri yang dihasilkan dari ekstrak daging dan jeroan $H$. atra bersifat bakteriostatik karena hanya mampu menghambat pertumbuhan bakteri. Hal ini sesuai dengan pendapat Dwijoseputro (2005) yang menyatakan bahwa senyawa yang bersifat bakteriostatik adalah senyawa yang hanya mampu menghambat pertumbuhan bakteri dengan tidak membunuhnya, sehingga jika bahan antibakterinya hilang atau rusak, maka bakteri uji akan dapat tumbuh kembali. Akan tetapi, aktivitas antibakteri dari ekstrak daging dengan konsentrasi $4000 \mu \mathrm{g} /$ disk terhadap bakteri $V$. alginolyticus tidak mengalami penurunan setelah inkubasi selama 48 jam sehingga ekstrak daging dengan konsentrasi tersebut bersifat bakteriocidal terhadap bakteri Vibrio alginolyticus.

Berdasarkan hasil uji aktivitas antibakteri ekstrak daging dan jeroan $H$. atra terhadap bakteri $B$. cereus dan $V$. alginolyticus membuktikan bahwa ekstrak daging lebih unggul dibandingkan ekstrak jeroan $H$. atra. Berdasarkan Tabel 1 dan Tabel 3, aktivitas antibakteri tertinggi pada ekstrak daging adalah 14214,08 $\mathrm{mm}^{2} / \mathrm{ml}$ dan ekstrak jeroan adalah $7858,72 \mathrm{~mm} / \mathrm{ml}$. Hasil ini disebabkan karena perbedaan jumlah senyawa metabolit sekunder seperti alkaloid, triterpenoid, dan saponin yang terkandung didalam sampel. Hal ini diperkuat dengan pernyataan Sari et al. (2014) yang menyatakan bahwa senyawa alkaloid, triterpenoid, dan saponin yang terkandung didalam ekstrak jeroan lebih sedikit dibandingkan ekstrak daging dimana senyawa-senyawa tersebut merupakan senyawa yang bekerja dengan menghambat serta merusak dinding sel dari bakteri.

Penelitian Pranoto et al. (2012) dan Septiadi et al. (2013) menyatakan bahwa Saponin berkontribusi sebagai antibakteri yang dapat menurunkan tegangan permukaan membran sehingga merusak sifat permeabilitas dari dinding sel bakteri $B$. cereus dan $V$. alginolyticus. Rusaknya sifat permeabilitas dari dinding sel menyebabkan cairan intraseluler yang lebih pekat seperti protein, enzim, dan zat-zat metabolisme bakteri lainnya tertarik keluar dari sel dan menyebabkan kematian dari bakteri tersebut. Senyawa triterpenoid dalam ekstrak menurut Bordbar et al. (2011) juga memiliki sifat antibakteri yang bekerja dengan mengganggu membran sel dan menghambat sintesis protein dari bakteri.

Hasil uji kontrol negatif menunjukkan bahwa tidak terbentuknya daya hambat dari pelarut terhadap bakteri uji, sehingga pelarut yang digunakan tidak berpengaruh terhadap aktivitas antibakteri pada saat pengujian dengan menggunakan ekstrak daging dan jeroan $H$. atra. Hal ini sesuai dengan pernyataan Rifai dan Trianto (2003) yang menyebutkan uji kontrol negatif dilakukan untuk mengetahui ada tidaknya pengaruh pelarut dalam pembentukan daya hambat.

Uji kontrol positif menggunakan kloramfenikol dengan konsentrasi $500 \mu \mathrm{g} /$ disk menunjukkan zona hambat yang lebih besar dibandingkan dengan ekstrak daging maupun jeroan dari $H$. atra. Uji kontrol positif terhadap bakteri $B$. cereus mendapatkan AU sebesar $94438,64 \mathrm{~mm}^{2} / \mathrm{ml}$ dan terhadap bakteri $V$. alginolyticus adalah 120689,39 $\mathrm{mm}^{2} / \mathrm{ml}$. Menurut Sari et al. (2014) hal ini dikarenakan kloramfenikol merupakan senyawa murni yang mempunyai mekanisme sebagai pengganggu sintesis protein dari bakteri sehingga dapat mengakibatkan kematian bakteri, sedangkan ekstrak $H$. atra merupakan ekstrak kasar dan masih mengandung berbagai senyawa lain yang dapat mempengaruhi kemampuan alkaloid, triterpenoid, steroid, flavonoid, dan saponin untuk menghambat pertumbuhan bakteri. Hal ini sesuai dengan pendapat Dewi et al. (2014) yang menyebutkan bahwa mekanisme kloramfenikol dalam menghambat bakteri dengan bergabung pada subunit-subunit ribosom, sehingga mencegah bergabungnya asam amino menjadi protein sehingga sintesis asam amino terganggu bahkan tidak berlangsung dan menyebabkan kematian sel bakteri. 


\section{KESIMPULAN}

Teripang $H$. atra berpotensi untuk dimanfaatkan sebagai makanan fungsional berbasis antibakteri yang menyehatkan tubuh karena memiliki akivitas antibakteri terhadap bakteri $B$. cereus dan V. Alginolyticus. Ekstrak daging dan jeroan $H$. atra dengan konsentrasi $500 \mu \mathrm{g} /$ disk tidak memiliki aktivitas antibakteri terhadap bakteri $B$. cereus dan $V$. alginolyticus pada inkubasi 24 dan 48 jam. Ekstrak jeroan $H$. atra dengan konsentrasi $1000 \mu \mathrm{g} /$ disk, $2000 \mu \mathrm{g} /$ disk, $4000 \mu \mathrm{g} /$ disk serta ekstrak daging $H$. atra dengan konsentrasi $1000 \mu \mathrm{g} /$ disk dan $2000 \mu \mathrm{g} /$ disk bersifat bakteriostatik terhadap bakteri $B$. cereus dan $V$. alginolyticus karena terjadi penurunan aktivitas antibakteri pada inkubasi 48 jam. Ekstrak daging $H$. atra dengan konsentrasi $4000 \mu \mathrm{g} /$ disk bersifat bakteriosidal terhadap bakteri $V$. alginolyicus karena tidak terjadi penurunan aktivitas antibakteri pada inkubasi 48 jam.

\section{DAFTAR PUSTAKA}

Bordbar, S., Anwar, F. \& Saari, N. 2011. High-Value Components and Bioactives from Sea Cucumber for Functional Foods - A Review. Marine Drugs. 9:1761-1805

Cushnie, T.P.T., Benjamart, C. \& Andrew, J.L. 2014. Alkaloids: An Overview of Their Antibacterial, Antibiotic-enhancing, and Antivirulence Activities. International journal of Antimicrobial Agents (44):377-386

Darsono, P. 1999. Perkembangan Pembenihan Teripang Pasir, Holothuria scabra Jaeger, Di Indonesia. Oseana, 24(3):35-45.

Dewi, M.K., Ratnasari, E. \& Guntur, T. 2014. Aktivitas Antibakteri Ekstrak Daun Majapahit (Crescentia cujete) terhadap Pertumbuhan bakteri Ralstonia solanacearum Penyebab Penyakit Layu. Lentera Bio, 3(1):51-57

Dwijoseputro. 2005. Dasar-Dasar Mikrobiologi. Gramedia: Jakarta.

European Commision Concerted Action on Functional Food Science in Europe. 1999. Scientific Concepts of Functional Foods in Europe Consensus Document. British Journal of Nutrition (81): S1-S27

Farouk, A.E., Faizal, A.H.G., \& Ridzwan, B.H.. 2007. New Bacterial Species Isolated from Malaysian Sea Cucumbers with Optimized Secreted Antibacterial Activity. American Journal of Biochemistry and Biotechnology. 3(2):60-65.

Inayah, N., Ningsih, R. \& Adi, T.K.. 2013. Uji Toksisitas dan Identifikasi Awal Golongan Senyawa Aktif Ekstrak Etanol dan N-Heksana Teripang Pasir (Holothuria scabra) Kering Pantai Kenjeran Surabaya. Alchemy, 2(1):92-100

Kaswandi, M.A., Lian, H.H., Nurzakiah, S., Ridzwan, B.H., Ujang, S., Samsudin, M.W., Jasnizar S. \& Ali, A.M. 2000. Crystal Saponin from Three Sea Cucumber Genus and Their Potential as Antibacterial Agents. $9^{\text {th }}$ Scientific Conference Elevtron Microscopic Society. 12-14 November 2000. Kota Bharu, Kelantan: 273-276.

Khotimchenko, Y. 2018. Pharmacological Potential of Sea Cucumber. International Journal of Molecular Sciences. 19(5):1342.

Oktaviani, D., Yeni, M. \& Emma, R. 2015. Aktivitas Antioksidan dan Antibakteri Ekstrak Jeroan Teripang Holothuria atra dari Perairan Pulau Biawak Kabupaten Indramayu. Jurnal Perikanan dan Kelautan 6(2):1-6.

Pranoto, E.N., Widodo F.M. \& Delianis P. 2012. Kajian Aktivitas Bioaktif Ekstrak Teripang Pasir (Holothuria scabra) Terhadap jamur Candida albicans. Jurnal Perikanan, 1(2): 1-8

Rifai, A. \& Trianto, A. 2003. Penggunaan Thin Layer Chromatogaphy untuk Mengidentifikasi Kandungan Bahan Bioaktif Antibakteri Vibrio harveyi pada Karang Lunak Sarcophyton sp. Fakultas Perikanan dan Ilmu Kelautan Undip: Semarang.

Sabdono, A. \& Radjasa, O.K. 2008. Microbial symbionts in Marine Sponges: Marine Natural Product Factory. Journal of Coastal Development., 11(2):57-61.

Sari E.M., Widodo F.M. \& Sumardianto. 2014. Kajian Senyawa Bioaktif Ekstrak Teripang Hitam (Holothuria edulis) Basah dan Kering sebagai Antibakteri Alami. Jurnal Pengolahan dan Bioteknologi Hasil Perikanan, 3(4):16-24. 
Septiadi, T., Delianis, P. \& Ocky K.R. 2013. Uji Fitokimia dan Aktivitas Antijamur Ekstrak Teripang Keling (Holothuria atra) dari Pantai Bandengan Jepara terhadap Jamur Candida albicans. Journal of Marine Science. 2(2):76-84.

Winarno. 2004. Kimia Pangan dan Gizi. Jakarta: Gramedia Pustaka Utama

Wiranto, E., Muhamad, A.W. \& Puji, A. 2016. Aktivitas Antiinflamasi secara In-Vitro Ekstrak Teripang Butoh Keling (Holothuria leucospilota Brandt) dari Pulau Lemukutan. Jurnal Kimia Khatulistiwa, 5(1):52-57 